\title{
Proteomic Analysis to Elucidate the Antibacterial Action of Silver Ions Against Bovine Mastitis Pathogens
}

\author{
Seog Jin Kang ${ }^{1}$ Yong Il $\mathrm{Cho}^{1} \cdot \mathrm{Ki}^{\mathrm{H} y u n} \mathrm{Kim}^{1} \cdot$ Eun Seok Cho ${ }^{1}$
}

Received: 1 September 2015 / Accepted: 7 September 2015 /Published online: 3 October 2015

(C) The Author(s) 2015. This article is published with open access at Springerlink.com

\begin{abstract}
Silver ions act as a powerful, broad-spectrum antimicrobial agent and are known to kill over 650 different kinds of pathogens. We investigated the protein expression pattern and identity after silver ion treatment in Escherichia coli and Staphylococcus aureus, which are primarily responsible for the majority of bovine mastitis cases using proteomics. Two-dimensional electrophoresis showed that silver ion treatment significantly reduced 5 spot's density in E. coli and $S$. aureus, respectively. We identified 10 proteins (alkyl hydroperoxide reductase C22 subunit, phosphoglucomutase, fructose-1-phosphate kinase, putative carbamoyl transferase, alpha-galactosidase, carbamate kinase, ornithine transcarbamoylase, fumarate hydratase class II, alcohol dehydrogenase, and conserved hypothetical protein) by matrix-assisted laser desorption ionization time of flight (MALDI-TOF). These results demonstrated that silver ions have bactericidal effects through energy deprivation, inhibition of DNA replication, and accumulation of oxidants in bovine mastitis pathogens and suggested that silver ions can be applied for the treatment of bovine mastitis.
\end{abstract}

Keywords Bactericidal effect · Mastitis · Proteomics ·

Silver ion

Ki Hyun Kim and Eun Seok Cho equally contributed to this work as cocorresponding authors.

Eun Seok Cho

segi0486@korea.kr

1 National Institute of Animal Science, Rural Development Administration, Cheonan 331-801, Republic of Korea

\section{Introduction}

Increasing resistance of pathogenic bacteria to bactericides and antibiotics due to the extensive use of these reagents now presents a more significant challenge for curing animal diseases $[1,2]$. Thus, the interest to identify alternative, safe, and cost-effective bactericidal materials to cure animal disease is growing. Silver has long been known to have strong inhibitory and bactericidal effects [3-5]. A silver ion solution is composed of submicroscopic, positively charged silver particles in an aqueous medium. Silver ions act as a powerful, broad-spectrum, antimicrobial agent and are known to kill over 650 different kinds of pathogens including bacteria, viruses, fungi, parasites, and molds [6-9]. Furthermore, silver ions are also extensively used for food preservation, decontamination, and disinfection of medical supplies [10]. A positive charge is the primary feature of silver particles, enabling them to aggressively attach to microbes and kill them [11-13]. Additionally, the naturally small size of silver ions permits them to pass through cell membranes [13-15].

Several studies have been conducted to explain the bactericidal effects of silver ions [2, 16, 17]. It is generally believed that heavy metals react with $\mathrm{SH}$ groups, which leads to the inactivation of the cellular proteins $[16,18]$ and inhibition of bacterial oxygen metabolism. Recent studies proposed that silver ions also react with the thiol group of enzymes to inactivate them [12,19] and interact with DNA [15], resulting in marked enhancement of pyrimidine dimerization by photodynamic reactions and possible prevention of DNA replication $[12,17]$. However, the mechanism underlying the antimicrobial effects of silver is still not fully understood. In particular, proteomic insights that may help elucidate the bactericidal mechanism of silver ions are still lacking. Furthermore, no study has been conducted to examine the bactericidal effects of silver ions against bacteria that cause bovine mastitis. 
The objective of this study was to investigate the mechanisms underlying the bactericidal effects of silver ions against bovine mastitis pathogens such as Escherichia coli (E. coli) and Staphylococcus aureus (S. aureus). For this, we used a proteomic approach to investigate the molecular aspects of this activity against $E$. coli and $S$. aureus.

\section{Materials and Methods}

Two reference strains (E. coli $\mathrm{O} 55$ and $S$. aureus 305 ) were obtained from Animal Plant and Fisheries Quarantine and Inspection Agency (Anyang, Korea). The bacteria were subcultured using Muller-Hinton agar plates (BD, USA). A large amount of microorganisms was scraped from the agar plate and used to inoculate test tubes containing Muller-Hinton broth (MHB; BD, USA). The MHB cultures were incubated at $37^{\circ} \mathrm{C}$ in ambient air until an optical density approximately equivalent to $1.0 \mathrm{McF}$ arland standard $\left(3 \times 10^{8} \mathrm{CFU} / \mathrm{mL}\right)$ was achieved.

Silver ions $(1000 \mu \mathrm{g} / \mathrm{mL})$ were prepared from aqueous $0.01 \mathrm{M}$ silver nitrate and various stabilizers (polyvinyl pyrrolidone and polyethylene) [20]. The $\mathrm{pH}$ of the solution was adjusted to 7.0 by adding sodium acetate. Silver ions were diluted $(50 \mu \mathrm{g} / \mathrm{mL})$ with pyrogen-free distilled water (Jungwei Pharma, South Korea).

Sample preparation E. coli and S. aureus $\left(2 \times 10^{7}\right.$ cells $)$ were incubated in $\mathrm{MHB}$ at $37^{\circ} \mathrm{C}$ for $2 \mathrm{~h}$ with or without silver ion $(50 \mu \mathrm{g} / \mathrm{mL})$ and then centrifuged at $3000 \times \mathrm{g}$ for $10 \mathrm{~min}$. Cell pellets were washed twice with ice-cold PBS and sonicated for 10 s using a Sonoplus (Bandelin Electronic, Germany) in icecold lysis buffer ( $8 \mathrm{M}$ urea, $4 \%$ CHAPS, and $20 \mathrm{mM}$ dithiothreitol). The lysates were centrifuged at $15,000 \times g$ for $10 \mathrm{~min}$ in a cold room, and the supernatants were collected.

Two-dimensional protein gel electrophoresis Protein samples $(60 \mu \mathrm{g}$ proteins) were subjected to isoelectrofocusing (IEF) on IPG strips (13 cm, pH 4-7) using the IPGphor IEF system(Ettan, USA). The first-dimension IEF conditions were $30 \mathrm{~V}$ for $10 \mathrm{~h}$ (rehydration) and $3500 \mathrm{~V}$ for $3 \mathrm{~h}$ with a total of $56 \mathrm{kVh}$. After IEF, the strips were incubated for $15 \mathrm{~min}$ in equilibration buffer (6 M urea, $30 \%$ glycerol, $2 \%$ SDS, and $50 \mathrm{mM}$ Tris-HCl, $\mathrm{pH}$ 6.8) containing $1 \%$ dithiothreitol and then for another $15 \mathrm{~min}$ in equilibration buffer containing $2.5 \%$ iodoacetamide. The strips were transferred onto $12.5 \%$ polyacrylamide slab gels containing $0.1 \%$ SDS and electrophoresed. All gels were visualized by silver staining as described by Oakley et al. [21].

Protein spot analysis Quantitative analysis of digitized images of the gels was carried out using PDQuest software (version 7.0, BioRad, USA) according to the protocols provided by the manufacturer. Each spot was normalized by the total valid spot intensity. Proteins with expression levels that changed more than twofold compared to the control sample were selected for further analysis.

MALDI-TOF MS/MS analysis Gel slices were destained with a solution of $50 \mathrm{mM}$ sodium thiosulfate and $15 \mathrm{mM}$ potassium ferricyanide, washed with water, and dehydrated in acetonitrile. The dehydrated gel slices were subjected to overnight in-gel tryptic digestion using sequencing grade trypsin (Promega, USA) according to manufacturer's instructions. The digested proteins were mixed with a saturation solution of R-cyano-4-hydroxycinnamic acid in $50 \%$ acetonitrile and $0.1 \%$ trifluoroacetic acid and spotted on the MALDI target plate. Peptide analysis was performed using matrix-assisted laser desorption ionization time of flight (MALDI-TOF) (Amersham Biosciences, UK). Peptides were evaporated with a N2 laser at $337 \mathrm{~nm}$, and a delayed extraction approach was used. The peptides were then accelerated with a $20 \mathrm{kV}$ injection pulse for time-of-flight analysis. Each spectrum was the cumulative average of 300 laser shots. The search program ProFound, developed by Rockefeller University (http:// 129.85.19.192/profound_bin/WebProFound.exe), was used for protein identification by peptide mass fingerprinting. Spectra were calibrated with trypsin auto-digestion ion peak $\mathrm{m} / \mathrm{z}$ $(842.510,2211.1046)$ as an internal standard.

\section{Results}

No significant or clear changes were observed between the bacteria cells treated with or without silver ions in the twodimensional protein gel electrophoresis (2-DE) images (Fig. 1). However, some spots in the 2-DE gels indicated decreased protein expression in silver ion-treated E. coli and S. aureus samples compared to the untreated cells. Spots corresponding to proteins with decreased expression caused by silver ion treatment were cut from the gels and analyzed using MALDI-TOF mass spectrometry (MS).

We investigated the results and revealed decreased expression of at least five proteins in each E. coli and $S$. aureus samples treated with silver ions (Fig. 2). Using the NCBI and Swiss-Prot databases for peptide mass fingerprinting, five proteins with decreased expression, the alkyl hydroperoxide reductase C22 subunit, phosphoglucomutase, fructose-1phosphate kinase, putative carbamoyl transferase, and alphagalactosidase, were identified in $E$. coli treated with silver ions (Table 1). The same fingerprinting databases identified the identity of five proteins with decreased expression, carbamate kinase, ornithine transcarbamoylase, fumarate hydratase class II, alcohol dehydrogenase, and a conserved hypothetical protein, in silver ion-treated S. aureus (Table 2). 
Fig. 1 2-DE images from $E$. coli cell (upper) and $S$. aureus cells (bottom) treated with or without silver ions. Analytical alkaline silver-stained 2-DE protein patterns obtained from suspensions of $E$. coli and $S$. aureus after incubating the cells with 0 and $50 \mu \mathrm{g} / \mathrm{mL}$ solution for $2 \mathrm{~h}$. 2-DE gel images of $S$. aureus cells treated with silver ions (b) and the untreated control (a)

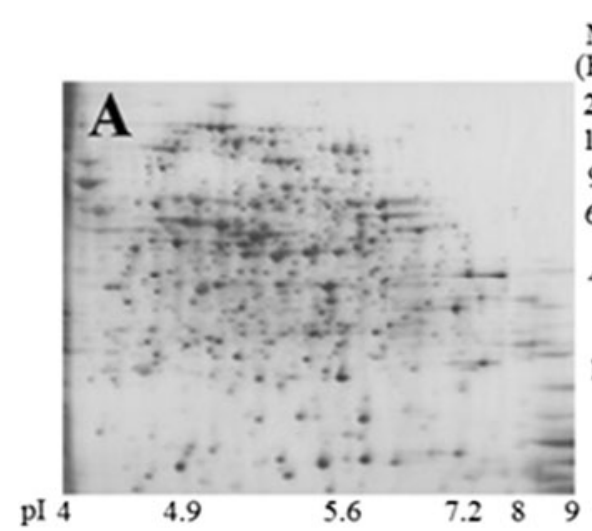

MW

(KDa)

200

120

95

66

43

18

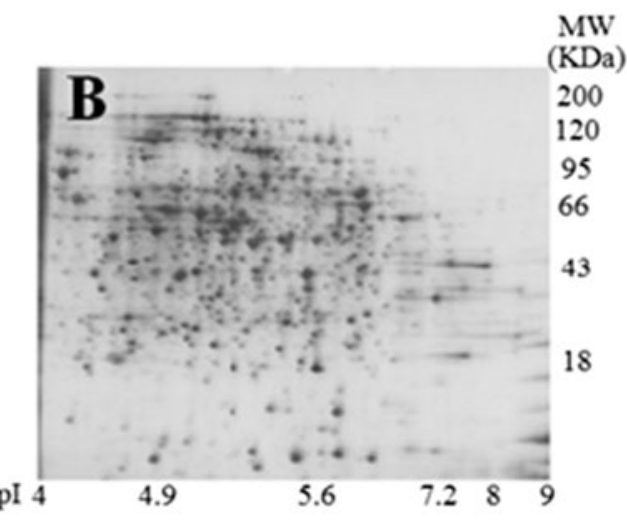

MW

(KDa)

200

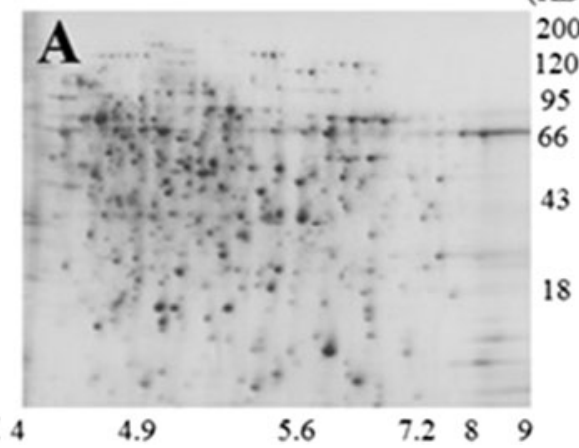

MW

20

95

66

43

8

MW

(KDa)

200
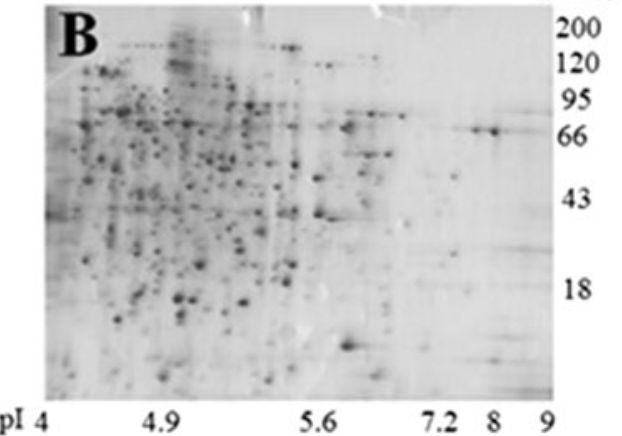
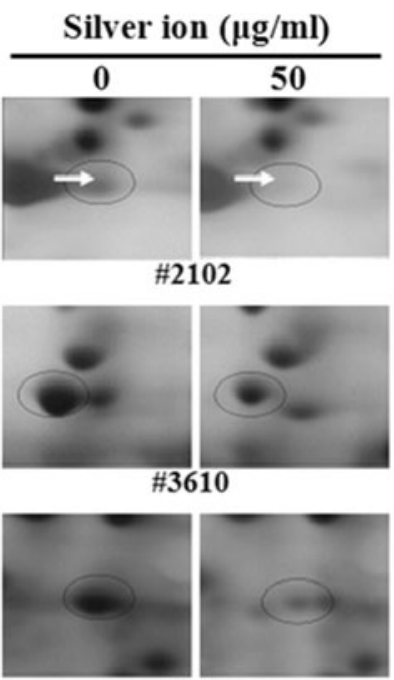

$\# 4303$

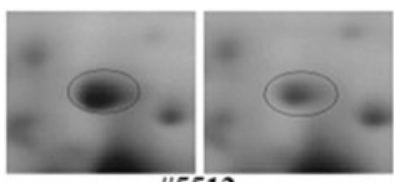

\#5512

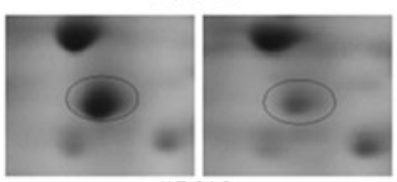

$\# 5610$
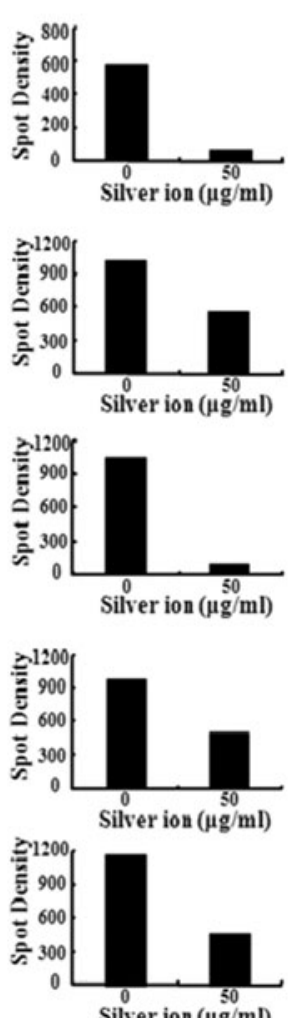

Silver ion $(\mu \mathrm{g} / \mathrm{mI})$

Fig. 2 Comparison of the expression profiles of proteins corresponding to five spots from the control and silver ion-treated $E$. coli cells (left) and $S$. aureus (right). Arrows show the relative spot density changes in the
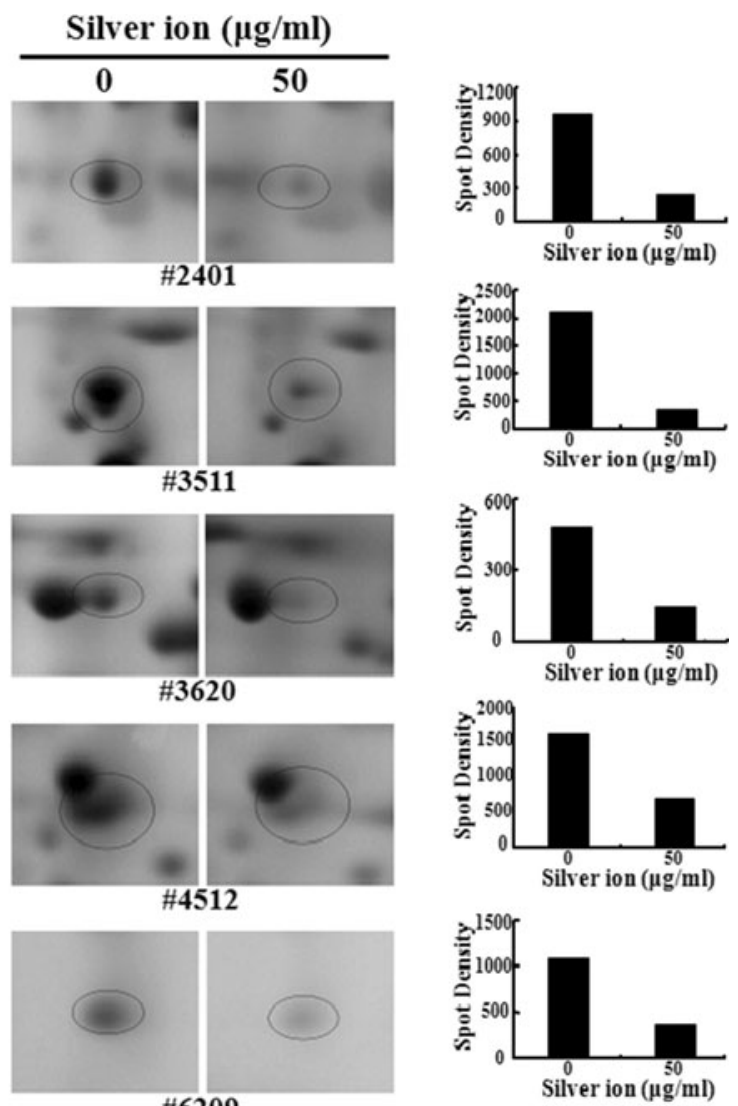

control and silver ion-treated E. coli cells and S. aureus. Bars represent the average density based on three different observations 
Table 1 Proteins identified in E. coli cells treated with silver ion using MALDI-TOF MS and searching the NCBI and Swiss-Prot databases for peptide mass fingerprinting

\begin{tabular}{|c|c|c|c|c|c|c|}
\hline \multirow[t]{2}{*}{ Spot number } & \multirow[t]{2}{*}{ Protein } & \multirow[t]{2}{*}{$\mathrm{pI}$} & \multirow[t]{2}{*}{ MW } & \multirow[t]{2}{*}{ Probability $^{*}$} & \multicolumn{2}{|l|}{ Density } \\
\hline & & & & & Control & Treatment \\
\hline 2102 & Alkyl hydroperoxide reductase $\mathrm{C} 22$ subunit & 5.0 & 20.86 & 67 & 577 & 62 \\
\hline 3610 & Phosphoglucomutase & 5.5 & 58.60 & 68 & 989 & 538 \\
\hline 4303 & Fructose-1-phosphate kinase & 5.4 & 33.97 & 32 & 1139 & 99 \\
\hline 5512 & Putative carbamoyl transferase & 5.5 & 44.51 & 73 & 982 & 435 \\
\hline 5610 & Alpha-galactosidase & 5.5 & 51.31 & 56 & 1157 & 390 \\
\hline
\end{tabular}

$p I$ isoelectric point, $M W$ molecular weight

*Probability based on the Mowse scoring algorithm

\section{Discussion}

Silver ions is a highly reactive moieties [11,22] and have a high affinity for proteins [23] which probably have caused structural changes in bacteria cells. Electrostatic attraction exists between negatively charged bacterial cells and positivelycharged silver ion [16] and is crucial for explaining the antibacterial effects of silver ions. The attachment of silver ions to cell proteins can significantly increase permeability, leaving the bacterial cells incapable of properly regulating transport through their plasma membrane and ultimately causing cell death. A similar effect was described by Klabunde et al. [8] when $E$. coli were treated with highly reactive metal oxide nanoparticles.

It is well known that the membrane of $E$. coli cells is predominantly constructed from tightly packed lipopolysaccharide (LPS) molecules which provide an effective barrier [4]. Amro et al. [24] have shown that attachment of a heavy metal to cell may cause the formation of irregular-shaped pits in the outer membrane and change membrane permeability, which is caused by progressive release of LPS molecules and membrane proteins. Once inside the cell, silver ions can probably bind to and denature bacterial DNA and RNA, thereby inhibiting its replication [14]. Feng et al. [15] reported the formation of electron-light regions in the cytoplasm and condensation of DNA molecules in E. coli and S. aureus that were exposed to a silver nitrate solution. Nover et al. [25] reported that a heat stimulus harmful to living cells may promote the conglomeration of some low molecular weight proteins around the nuclear region. Silver could cause a different type of shock to living cells than heat treatment; however, it is possible that some proteins that congregate around the nuclear region of silver ion-treated bacteria may protect the DNA molecules which were seen in energy-filtering transmission electron microscopy (EFTEM) results [13]. Rapid attachment and easy diffusion of silver ions into bacteria cells can cause the expansion of electron-light regions and collapse of cell walls.

It is well known that the replication of DNA is only possible when the molecules are in a relax state [26]. However, in the present study, no cell growth or multiplication was observed in bacteria that were continuously incubated with silver ions. One probable reason to this was the condensation of DNA caused by silver ions that could lower the ability of the DNA to replicate $[15,27]$. It was further demonstrated that heavy metals can bind the thiol group when present inside the cell and thus inhibit the activity of various enzymes [7, 19, $28]$, thereby leading to cellular death [16, 29]. Silver is a type

Table 2 Proteins identified in S. aureus cells treated with silver ions using MALDI-TOF MS and searching the NCBI and Swiss-Prot databases for peptide mass fingerprinting

\begin{tabular}{|c|c|c|c|c|c|c|}
\hline \multirow[t]{2}{*}{ Spot number } & \multirow[t]{2}{*}{ Protein } & \multirow[t]{2}{*}{$\mathrm{pI}$} & \multirow[t]{2}{*}{ MW } & \multirow[t]{2}{*}{ Probability $^{*}$} & \multicolumn{2}{|l|}{ Density } \\
\hline & & & & & Control & Treatment \\
\hline 2401 & Carbamate kinase & 5.0 & 34.48 & 83 & 1083 & 272 \\
\hline 3511 & Ornithine transcarbamoylase & 5.1 & 37.86 & 51 & 2228 & 392 \\
\hline 3620 & Fumarate hydratase, class II & 5.1 & 51.37 & 28 & 520 & 119 \\
\hline 4512 & Alcohol dehydrogenase & 5.3 & 36.43 & 69 & 1698 & 576 \\
\hline 6209 & Conserved hypothetical protein & 5.7 & 20.89 & 51 & 1053 & 361 \\
\hline
\end{tabular}

$p I$ isoelectric point, $M W$ molecular weight

*Probability based on the Mowse scoring algorithm 
of heavy metal that can induce the deposition of proteins in the cells. Considering this, the small electron-dense granules outside the electron-light region could be deposits of silver and proteins.

The previous report suggests that the bactericidal effects of the silver ion involved interaction of silver ion with the cytoplasm in the interior of the cell using EFTEM $[13,15]$. Initially, the silver ions appear to penetrate through ion channels without causing damage to the cell membranes. Once inside the cells, great affinity to bind with proteins and small size of silver ion lead it to attach and penetrate the bacterial cells that resulted in morphological distortion, particularly formation of a large gap between the cytoplasm membrane and the cell wall. Silver is a kind of heavy metal that can cause the deposition of proteins in the cells. Therefore, the entrance of silver into bacterial cells may lead to the deposition of proteins in cells.

In this study, we observed that silver ions can depress the activity of cytosolic proteins essential for glycolysis, the synthesis of amino acids, purines, pyrimidines, and nucleotides. Proteomic analysis of the silver-treated bacteria revealed decreased expression of enzymes involved in glycolysis (phosphoglucomutase, fructose-1-phosphate kinase, alpha-galactosidase, and alcohol dehydrogenase); the synthesis of amino acids, purines, pyrimidines, and nucleotides (putative carbamoyl transferase, carbamate kinase, ornithine transcarbamoylase, and fumarate hydratase class II); and detoxification (alkyl hydroperoxide reductase C22 subunit). Since the glucose pathway and tricarboxylic acid (TCA) cycle play substantial roles in the ATP production in the electron transport chain, inhibition of these enzymes by silver ions can inhibit this process which is indispensable for maintaining cell life. Inhibition of the enzymes involved in amino acid, purine, pyrimidine, and nucleotide metabolism can affect cell growth, protein synthesis, and DNA expression. Inhibition of detoxifying proteins can expose the bacterial cell to auto-oxidation because of the continuous accumulation of oxidants. Energy deficiency, inhibition of protein expression, its depressed function, and higher oxidation pressure could lead to damage and the death of silver ion-treated bacteria. These processes seem to render the cell unable to sustain membrane structures and thus cause cell disruption.

\section{Conclusion}

The results of this study indicated that treatment with silver ions $(50 \mu \mathrm{g} / \mathrm{mL}$ for $2 \mathrm{~h}$ ) could kill bacteria that cause bovine mastitis (E. coli and $S$. aureus). Great affinity for proteins and small size enable the silver ions to attach to and penetrate the bacterial cells. Moreover, the affinity of silver ion to cellular proteins disrupts glycolysis, amino acid synthesis, nitrogen base metabolism, and detoxifying capabilities of bacterial cells. Energy deprivation, inhibition of DNA expression, and accumulation oxidants resulted in cell wall disruption and death of silver ion-treated bacteria. The results indicate that silver ion has a bactericidal capacity against bovine mastitis bacterial pathogens, which may be amenable to treatment of bovine mastitis.

Acknowledgments This work was carried out with the support of "Cooperative Research Program for Agriculture Science \& Technology Development (Project No. PJ010532012015)” Rural Development Administration, Republic of Korea. This study was supported by 2015 Postdoctoral Fellowship Program of National Institute of Animal Science, Rural Development Administration, Republic of Korea.

Open Access This article is distributed under the terms of the Creative Commons Attribution 4.0 International License (http:// creativecommons.org/licenses/by/4.0/), which permits unrestricted use, distribution, and reproduction in any medium, provided you give appropriate credit to the original author(s) and the source, provide a link to the Creative Commons license, and indicate if changes were made.

\section{References}

1. Bechert T, Steinrucke P, Guggenbichler JP (2000) A new method for screening anti-infective biomaterials. Nat Med 6:1053-1056

2. Seol JW, Hur TY, Jung YH, Kang SJ, Park SY (2010) Evaluation of bactericidal capacity of silver ion against bovine mastitis pathogens. $\mathrm{J}$ Vet Clin 27:252-256

3. Fox CL (1968) Silver sulfadiazine-a new topical therapy for Pseudomonas in burns. Therapy of Pseudomonas infection in burns. Arch Surg 96:184-188

4. Berger TJ, Spadaro JA, Bierman R, Chapin SE, Becker RO (1996) Electrically generated silver ions: quantitative effects on bacterial and mammalian cells. Antimicrob Agents Chemother 10:357-358

5. Furr JR, Russell AD, Turner TD, Andrews A (1994) Antibacterial activity of Actisorb Plus, Actisorb and silver nitrate. J Hosp Infect 27:201-208

6. Berger TJ, Spadaro JA, Bierman R, Chapin SE, Becker RO (1976) Antifungal properties of electrically generated metallic ions. Antimicrob. Agents Chemother 10:856-860

7. Zhanel GG, Karlowsky JA, Davidson RJ, Hoban DJ (1992) Effect of pooled human cerebrospinal fluid on the postantibiotic effects of cefotaxime, ciprofloxacin, and gentamicin against Escherichia coli. Antimicrob Agents Chemother 36:1136-1139

8. Klabunde KJ, Koper OB, Klabunde JS (2002) Nanoscale powders and formulations with biocidal activity toward spores and vegetative cells of bacillus species, viruses, and toxins. Curr Microbiol 44: 49-55

9. Shin HS, Yang HJ, Kim SB, Lee MS (2004) Mechanism of growth of colloidal silver nanoparticles stabilized by polyvinyl pyrrolidone in $\gamma$-irradiated silver nitrate solution. J Colloid Interface Sci 274: 89-94

10. Hotta M, Nakajima H, Yamamoto K, Aono M (1998) Antibacterial temporary filling materials: the effect of adding various ratios of Ag-Zn-zeolite. J Oral Rehabil 25:485-489

11. Coward JE, Carr HS, Rosenkranz HS (1973) Silver sulfadiazine: effect on the ultrastructure of Pseudomonas aeruginosa. Antimicrob Agents Chemother 3:621-624

12. Seol JW, Kang SJ, Park SY (2010) Silver ion treatment of primary cultured bovine mammary gland epithelial cell (BMEC) damage from Staphylococcus aureus-derived $\alpha$-toxin. Vet Re Commun $34: 33-42$ 
13. Kang SJ, Seol JW, Hur TY, Jung YH, Park SY (2011) Morphological changes associated with the antibacterial action of silver ions against bovine mastitis pathogens. J Vet Clin 28:576580

14. Mermel LA, Stolz SM, Maki DG (1993) Surface antimicrobial activity of heparin-bonded and antiseptic-impregnated vascular catheters. J Infect Dis 167:920-924

15. Feng QL, Wu J, Chen GQ, Cui FZ, Kim TN, Kim JO (2000) A mechanistic study of the antibacterial effect of silver ions on Escherichia coli and Staphylococcus aureus. J Biomed Mater Res 52:662-668

16. Liau SY, Read DC, Pugh WJ, Furr JR, Russell AD (1997) Interaction of silver nitrate with readily identifiable groups: relationship to the antibacterial action of silver ions. Lett Appl Microbiol 25:279-283

17. Lansdown AB (2002) Silver. I: Its antibacterial properties and mechanism of action. J Wound Care 11:125-130

18. Kawahara KK, Tsuruda M, Uchida M (2000) Antibacterial effect of silver-zeolite on oral bacteria under anaerobic condition. Dent Mater J 16:452-455

19. Matsumura YK, Yoshikata S, Tsuchido T (2003) Mode of bactericidal action of silver zeolite and its comparison with that of silver nitrate. Appl Environ Microbiol 69:4278-4281

20. Wright JB, Lam K, Hansen D, Burrell RE (1999) Efficacy of topical silver against fungal burn wound pathogens. Am J Infect Control $27: 344-350$
21. Oakley BR, Kirsch DR, Morris NR (1980) A simplified ultrasensitive silver stain for detecting proteins in polyacrylamide gels. Anal Biochem 105:361-363

22. Kumar R, Munstedt H (2005) Silver ion release from antimicrobial polyamide/silver composites. Biomaterials 26:2081-2088

23. Ovington LG (2001) Battling bacteria in wound care. Home Healthc Nurse 19:622-630

24. Amro NA, Wadu-Mesthrige K, Liu GY (2003) Immobilization of proteins on self-assembled monolayers. Scanning 6:380-388

25. Nover L, Scharf KD, Neumann D (1983) Formation of cytoplasmic heat shock granules in tomato cell cultures and leaves. Mol Cell Biol 3:1648-1655

26. Modak SM, Fox CL (1973) Binding of silver sulfadiazine to the cellular components of Pseudomonas aeruginosa. Biochem Pharmacol 22:2391-2404

27. Lok CN, Ho CM, Chen R (2006) Proteomic analysis of the mode of antibacterial action of silver nanoparticles. J Proteome Res 5:916-924

28. Holt KB, Bard AJ (2005) Interaction of silver (I) ions with the respiratory chain of Escherichia coli: an electrochemical and scanning electrochemical microscopy study of the antimicrobial mechanism of micromolar Ag+. Biochem 44:13214-13223

29. Shekhar A, Soumyo M, Suparna M (2013) Immobilized silver nanoparticles enhance contact killing and show highest efficacy: elucidation of the mechanism of bactericidal action of silver. Nanoscale 5:7328-7340 